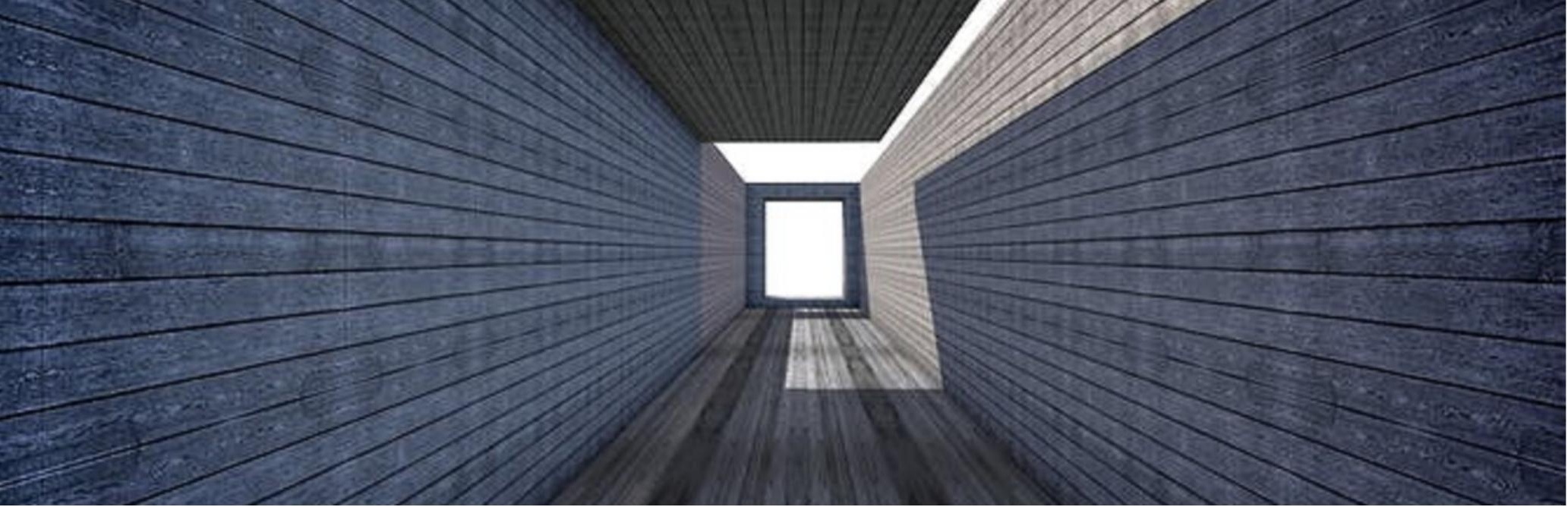

\title{
New Urban Agenda - How far -by the spatial planning legislation in Kosovo and Albania?
}

Authors: $\quad$ Elvida Pallaska, Vlora Navakazi, Bardha Meka

Submitted:

24. May 2018

Published: $\quad$ 18. June 2018

Volume: 5

Issue: $\quad 5$

Affiliation: Norwegian University of Science and Technology, Trondheim, Norway.

Languages: English

Keywords: $\quad$ Sustainable Urban Development, Sustainable Development Goals, Inclusive Human Settlements, Resilient Cities

DOI: $\quad$ 10.17160/josha.5.5.435 


\title{
New Urban Agenda - \\ How far -by the spatial planning legislation in Kosovo and Albania
}

\author{
Elvida Pallaska ${ }^{1}$,Vlora Navakazi ${ }^{2}$,Bardha Meka ${ }^{3}$ \\ 4,
}

November 2017

Prishtina

${ }^{1}$ UBT-Higher Education Institution,Kosovo, PHD-elvida.pallaska@ubt-uni.net;

${ }^{2}$ UP Kosovo,Prof.Ass. - vlora.navakazi@uni-pr.edu;

${ }^{3}$ UP Kosovo,Ass.Prof. - bardha.meka@uni-pr.edu; 


\begin{abstract}
Sustainable Urban Development in Kosovo and Albania is subject to this research paper. Analyzes of spatial planning documents and legislation of Kosova and Albania, toward approaching New Urban Agenda, as benchmarking to sustainable development, its strategic objectives, priorities, modalities is of importance.

Kosovo and Albanian cities are facing rapid urbanization due to several developmental and transitional reasons, migration, economic development challenges, initially regulated by spatial planning legislation followed by spatial planning documents.

Global trends says that one third of the global population will live in cities by 2050 (UN, 2014), in Albania over two third of population will live in cities after 2035 (UN, World Urbanization Prospects, 2009 Revision).

Key words: Sustainable Urban Development, Sustainable Development Goals, Inclusive Human Settlements, Resilient Cities
\end{abstract}

\title{
CHAPTER 1 - 1.1. BACKGROUND
}

The main motivation to this research is whether our cities in Kosova and Albania do progress toward Sustainable Urban Development, documented by their spatial planning legislation and documents, through indicators of New Urban Agenda as benchmarking document of EU and the UN.

"In the year 2050, two third of global population would be living in urban zones. Small and medium sized cities in developed countries are growing. Motivated cities are searching sustainable designs of cities"(United Nations, 2014).

Cities in Kosova and Albania do face the same trends as other cities in Europe and the world, of rapid urbanisation, ilegal construction, urban sprawl, expansion of the constructions with no criteria, eventhough might be said that spatial planning legislation and documents are in place and says different.

Cities in Kosova are magnets to population density, cause and source of urban problems. The word, term, notion of "CITY" is not included in Kosovo's spatial legislation of 2013, whereas cities are defined as only urban areas. Lack of managed and coordinated, integrated development plans that will regulate all spheres of development, while ad - hoc spread of developments are taking place.

At the Millenium Summit in September 2000, UN adopted declaration of 9 set Millenium Development Goals, where none of them was dealing with cities directly, eventhough in cities are many social negative developments, crime, hunger, poverty, unemployment, land devastation, environmental degradations, climate change etc.

As of 1st of January 2016, the 17 Sustainable Development Goals of the 2030 Agenda for Sustainable Development is in force, with the 11th as Goal for the "Sustainable Cities". It is obvious the concern of the world for the phenomenas of cities linked with all other negative social reflections. All the Sustainable Development Goals are having in comon the same benchmark Sustainable Development.

European Union, in the same time has been issued the "Urban Agenda for the EU" - 'PACT OF AMSTERDAM', as document and approach to healthier and sustainable developed cities. Its "Ongoing Process" for achievement of strategic objectives: priorities, partnerships, operations, member states, urban authorities, working programme, governance. 
The European Union - the most urbanised areas in the world. More than 70\% of Europe's citizens lives in an Urban Area. By 2050 this percentage will reach 80\%; All jobs/73\% and 80\% of people (aged 25-64) with a tertiary education are based in European cities, towns and suburbs; Urban Areas - challenges such as segregation, unemployment, and poverty are concentrated. Urban Areas play a key role in pursuing the EU 2020 objectives; Urban Authorities play a crucial role in the daily life of all EU citizens; The success of European sustainable urban development is highly important for the economic, social and territorial cohesion of the European Union and the quality of life of its citizens.

\subsection{OBJECTIVES, HYPOTHESIS AND RESEARCH QUESTIONS}

\section{OBJECTIVES -}

Objectives to this research paper are: Evaluation of the extent of inclusion of Urban Agenda (UN and EU) in Kosova and Albania Spatial Planning legislation and spatial planning documents, on their way to Sustainable Development.

1. Hypotheses are: 1) Kosovo Spatial Legislation and Plans DO NOT include indicators from Urban Agenda's; 2) Albania Spatial Legislation might be the ONE, while the developments are showing different; 3) Kosovo and Albania spatial legislation and plans MUST undergo indicators of URBAN AGENDA (UN \&EU) as pathway to Sustainable Development!

\section{RESEARCH QUESTIONS -}

1. Does and in what extent the Kosovo and Albania legislation take into consideration NEW URBAN AGENDA as pathway to Sustainable Urban Development?

2. What is missing in KS and AL legislation to fulfil the NUA as pathway to Sustainable Urban Development?

3. What orientation KS and AL National Development Plans are taking vs NUA?

\section{RESEARCH OBJECTIVES-}

1. To examine and list main gaps of Spatial Planning Laws in Kosovo and in Albania toward New Urban Agenda!

2. To examine and list main gaps of National Spatial Planning Documents of Kosovo and in Albania toward New Urban Agenda!

3. To be proposed the list of main changes to Spatial Planning Laws of Kosovo and Albania toward fulfilment of New Urban Agenda!

\section{CHAPTER 2. - 2.1. LITERATURE REVIEW}

To what extent "Sustainable Urban Development" is included in other countries legislation? Every country has its legislation for spatial development, using the potential of urban zones, through their sectoral policies and government levels. Potentials of urban zones often are limited and obstructed by limitations from their spatial legislations - having impacts in Governance /Urban Dimension. In Urban Development Legislations, governance is spread between different urban authorities and other stakeholders: civil society, businesses, education institutions that can be defined as formers

of the future urban entity. 


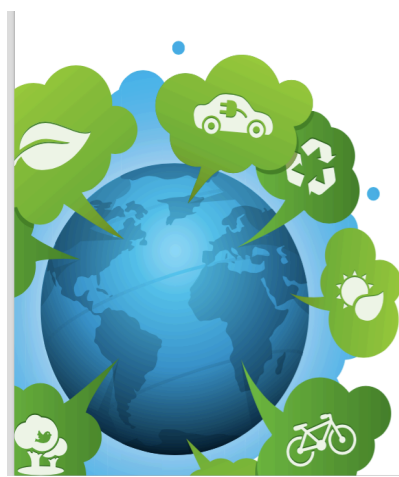

An important European environmental policy aim is to create "sustainable cities". There are tensions between environmental measures and urban spatial planning law to create such sustainable cities and examine opportunities for integrated sustainable urban planning, crucial to creation of sustainable urban environment.

Urban Sustainability Indicators - Urban Sustainability Indicator framework- developed by the European Foundation for the Improvement of Living and Working Conditions, / Charter of European Sustainable Cities and Towns, (Aarlborg Commitments).

UN NEW URBAN AGENDA - New global standard for sustainable urban development, will help us rethink how we plan, manage and live in cities. Roadmap for building cities that can serve as engines of prosperity and centres of cultural and social well-being while protecting the environment; Provides guidance for achieving the Sustainable Development Goals and provides the underpinning for actions to address climate change.

UN NEW URBAN AGENDA OBJECTIVES/INDICATORS -Climate change addressing by reducing their greenhouse gas emissions - (Leaders have committed to involve not just the local government but all actors of society to take climate action taking into account the Paris Agreement on climate change which seeks to limit the increase in global temperature to well below 2 degrees Celsius. Sustainable cities that reduce emissions from energy and build resilience can play a lead role).

Promote safe, accessible and green public spaces - (Human interaction should be facilitated by urban planning, which is why the Agenda calls for an increase in public spaces such as sidewalks, cycling lanes, gardens, squares and parks. Sustainable urban design plays a key role in ensuring the liveability and prosperity of a city).

Improve connectivity and support innovative and green initiatives - (This includes establishing partnerships with businesses and civil society to find sustainable solutions to urban challenges)

How will this be achieved? - (The New Urban Agenda will require new urban rules and regulations, improved urban planning and design, and municipal finance, among other things)

Strengthen city resilience - reduce risk and impact of disasters / Many cities - impact of natural disasters, leaders committed to implement mitigation and adaptation measures: Better urban planning, quality infrastructure and improving local responses . Address climate changereducing greenhouse gas emissions. Leaders committed to involve local government, all actors of society to take climate action taking into account the Paris Agreement on climate change.

Promote safe, accessible and green public spaces - Human interaction should be facilitated by urban planning, increase in public spaces: sidewalks, cycling lanes, gardens, squares and parks. Improve connectivity and support innovative and green initiatives - This includes establishing partnerships with businesses and civil society to find sustainable solutions to urban challenges. The New Urban Agenda will require new urban rules and regulations, improved urban planning and design, and municipal finance, among other things.

URBAN AGENDA FOR THE EU - 'PACT OF AMSTERDAM' OBJECTIVES/INDICATORS - The AIM of the AGENDA is represented by three columns: 1.Better regulations; 2.More efficient financial sources;3.Better Knowledge, whereas the same indicators 
METHODOLOGY - Spatial Planning Law of Kosovo and Albania as well as Spatial Planning documents are evaluated as per indicators of "UN - New Urban Agenda" and of "Urban Agenda for EU" indicators, to quantify to what extent they fulfill the criteria's, in order to qualify what should be done in order to improve the spatial legislation and spatial planning documents of Kosovo and Albania.

The evaluation of the indicators has been ranged in three categories in positive, neutral and negative:

$(+)(+)(+)$ - Detailed specification

$(+)(+)$ - Specified under objective but low priority and

$(+)$ - Limited specification under objective and not as priority,

(0) - Neutral not specified issues/being under general objectives

(-) - Limited specification under objective and not as priority,

$(-)(-)$ - Not specified but generalized under the objective

$(-)(-)(-)$ Not mentioned at all as policy, priority nor objective

CHAPTER 3. - 3.1. ANALYSES OF SPATIAL PLANNING LEGISLATION AND DOCUMENTS/KOSOVO AND ALBANIA SUSTAINABLE URBAN DEVELOPMENT

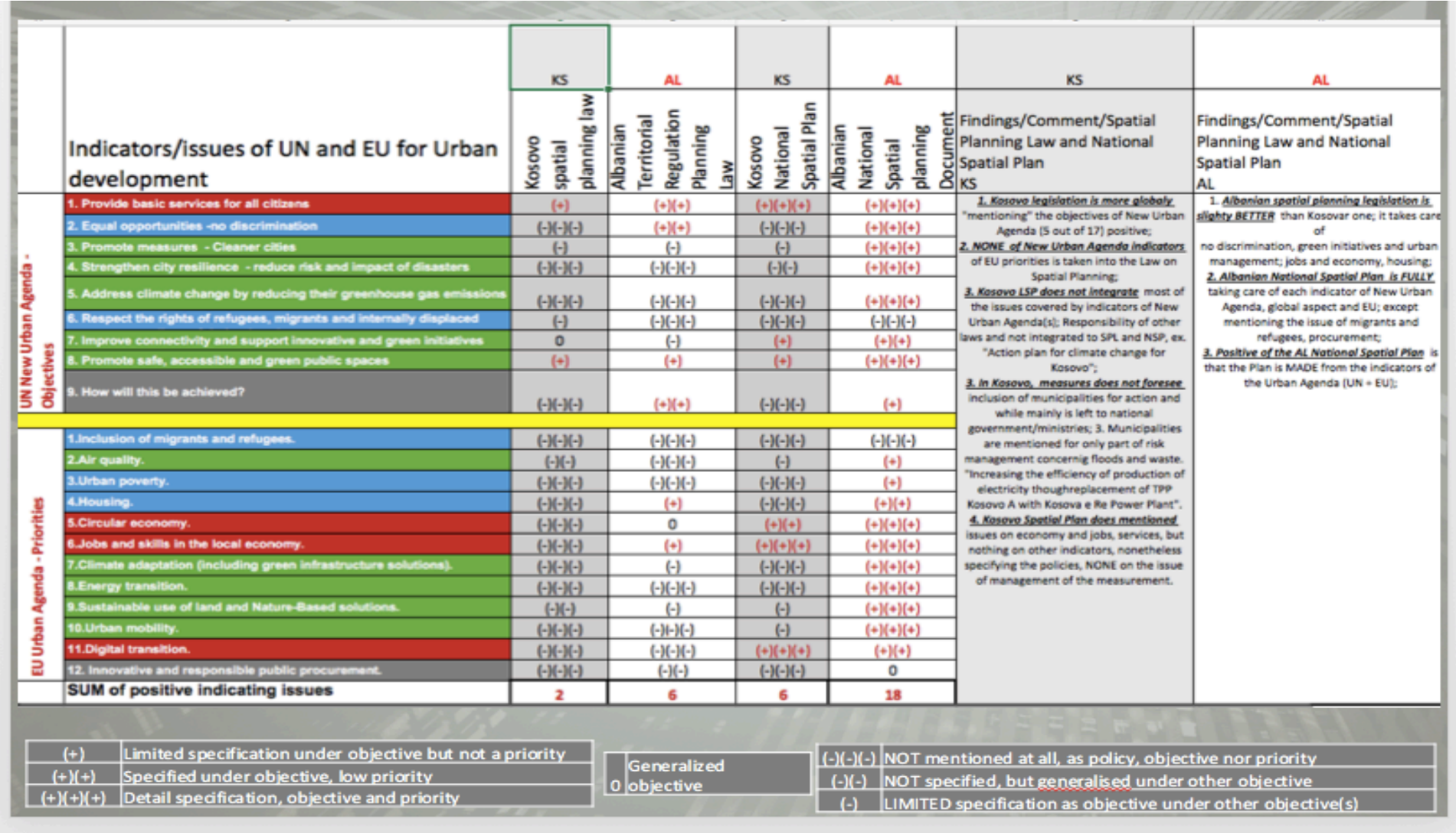




\section{CHAPTER 4. - FINDINGS, CONCLUSIONS AND RECCOMENDATIONS}

\subsection{FINDINGS}

4.1.1. Kosovo-legislation (2 of $\max 63)$

4.1.1. Kosovo - Spatial Planning document evaluation (6 of max 63) $=10 \%$

1. Kosovo legislation is more globally "mentioning" the objectives of New Urban Agenda (5 out of 17) positive;

2. NONE of New Urban Agenda indicators of EU priorities is taken into the Law on Spatial Planning;

3. Kosovo LSP does not integrate most of the issues covered by indicators of New Urban Agenda(s); Responsibility of other laws and not integrated to SPL and NSP, ex. "Action plan for climate change for Kosovo";

3. In Kosovo, measures does not foresee inclusion of municipalities for action and while mainly is left to national government/ministries; 3. Municipalities are mentioned for only part of risk management concernig floods and waste. "Increasing the efficiency of production of electricity thoughreplacement of TPP Kosovo A with Kosova e Re Power Plant".

4. Kosovo Spatial Plan does mentioned issues on economy and jobs, services, but nothing on other indicators, nonetheless specifying the policies, NONE on the issue of management of the measurement.

\subsubsection{Albania - spatial planning legislation (6 of max 63)$$
=10 \%
$$ \\ 4.1.1. Albania- Spatial Planning document (18 of max 63)$$
=29 \%
$$

1. Albanian spatial planning legislation is slighty BETTER than Kosovar one; it takes care of no discrimination, green initiatives and urban management; jobs and economy, housing;

2. Albanian National Spatial Plan is FULLY taking care of each indicator of New Urban Agenda, global aspect and EU; except mentioning the issue of migrants and refugees, procurement;

3. Positive of the AL National Spatial Plan is that the Plan is MADE from the indicators of the Urban Agenda (UN + EU);

\subsection{CONCLUSIONS}

1. Kosovo and Albania legislation DOES NOT take into consideration NEW URBAN AGENDA indicators as pathway to Sustainable Urban Development, to a very large extent!

2. In KS and AL legislation the main points to fulfilment of NUA as pathway to Sustainable Urban Development, would be as many issues, indicators as for revision of the spatial planning legislation of two countries!

3. Kosovo and Albania National Development Plans DOES NOT fulfil all issues as per indicators of New Urban Agenda, where in Kosovo case, to a very large extent, while in Albania case to fewer extent! 


\subsection{RECCOMENDATIONS}

Spatial Legislation of Kosovo and Albania should -Modernize governance through administrativeterritorial reforms affecting the Constitution of the countries. Identify "Development Strategies" rather than "Plan Plans" with a hierarchy of plans but with the System of Regions by meeting the 6 criteria for regionalization. Specify the need for sustainable urban development based -on concrete facts on the urban challenges of the countries. Specify concrete and prioritized objectivesfollowed by applicable developmental measures; Identify urban parameters - and the impact of urban areas on sustainable development. Identify "Sustainable Development Players" - during public participation process; Identify inclusion of urban dimension - in policy simplification, exploitation of GIS, by provision of effective of new and comprehensive knowledge strategies. Include the "Smart Cities" - in the content of the legislation. Initiate partnerships - as strategic mechanisms of urban policymaking and regionalization. Extend beyond - the conceptual involvement in processes, actions, solutions, and mechanisms of distribution of the monitoring process. Provide polycentrism- for the development of territorial cohesion.

\section{REFERENCES}

- "The European Urban Agenda - "Pact of Amsterdam", Netherlands, 2016.

- Urban sustainability issues - What is a resource-efficient city?" European Environment Agency, Luxembourg, 2015;

- The Sustainable Development Goals Report 2016, United Nations, Department of Economic and Social Affairs (DESA)

- $\quad$ Science for Environment Policy (2015) Indicators for sustainable cities. In-depth Report 12. Produced for the European Commission DG Environment by the Science Communication Unit, UWE, Bristol.

- "Spatial Planning Law of Kosovo" (2013)

- $\quad$ "Spatial Planning Law of Albania" (2014)

- $\quad$ "The Urban dimension of EU policies - key features of an EU Urban Agenda, European Union (2014)

- $\quad$ "Investments for Jobs and Growth-Promoting Development and Good Governance in EU Regions and Cities - *6th Report on Economic, Social and Territorial Cohesion, European Commission (2014)

- "Rural-Urban Partnerships: An Integrated Approach to Economic Development", OECD (2013)

- "European Magazine-Urban Developments", Soros (2012)

- "Spatial Plan of Kosovo 2010-2020" - Ministry of Spatial Planning (2010)

- $\quad$ "Indicators - Indicators for Spatial Planning" - Ministry of Environment and Spatial Planning, Kosovo Environmental Protection Agency, Spatial Planning Institute, (2016)

- $\quad$ "Regionalization of Albania" - The governance, administrative and territorial reform that needs Albania at the regional level. Institute for Habitat Development (2014) 